\title{
Restricted Eating with Weight Loss Selectively Decreases Extracellular Dopamine in the Nucleus Accumbens and Alters Dopamine Response to Amphetamine, Morphine, and Food Intake
}

\author{
Emmanuel N. Pothos, ${ }^{1}$ lan Creese, ${ }^{2}$ and Bartley G. Hoebel ${ }^{1}$ \\ 'Department of Psychology, Program in Neuroscience, Princeton University, Princeton, New Jersey 08544-1010 \\ and ${ }^{2}$ Center for Molecular and Behavioral Neuroscience, Rutgers-The State University of New Jersey, Newark, \\ New Jersey 07102
}

Weight loss is known to alter food intake and drug selfadministration, but the neural basis of this is unknown. Therefore, we studied effects of weight loss on neurochemistry of a brain mechanism involved in behavior reinforcement. In rats reduced $20-30 \%$ below normal weight, basal extracellular dopamine (DA) in the nucleus accumbens (NAC) decreased up to $50 \%(p<0.01)$, as measured by in vivo microdialysis. No such change was observed in dorsal striatum (STR) or medial prefrontal cortex. In underweight rats, systemic amphetamine $(1.5 \mathrm{mg} / \mathrm{kg}$ i.p.) transiently restored extracellular DA, but only to basal normal levels. Morphine (20 $\mathrm{mg} / \mathrm{kg}$ i.p.) or a meal also increased DA, but the percent increase was significantly smaller in underweight than normal weight animals. Amphetamine infused locally by reverse dialysis in the NAC increased extracellular DA more in underweight animals than controls, suggesting that DA had accumulated in the presynaptic terminals. This was confirmed by finding significantly more DA in homogenized NAC micropunches of underweight rats. Receptor counts in micropunches and quantitative receptor autoradiography showed ${ }^{3} \mathrm{H}-\mathrm{SCH} 23390$ and ${ }^{3} \mathrm{H}-\mathrm{spi}-$ perone $D_{1}-$ and $D_{2}$-type binding in the NAC, STR, frontal cortex and hypothalamus did not change significantly. Locomotor activity was depressed suggesting that low DA release in the NAC may be related to energy conservation during weight loss. Low extracellular DA may also underlie the increase in food and drug intake typically observed in underweight animals and humans when they attempt to restore extracellular DA levels by natural or artificial means.

[Key words: body weight, dopamine, nucleus accumbens, amphetamine, morphine, food intake, microdialys/s, autoradiography, locomotion, drug abuse]

Chronic food deprivation and subsequent weight loss have been found to incrcasc drug-seeking behavior and voluntary drug intake in animals (Carroll et al., 1979; Carroll and Stotz, 1983; Carroll; 1985; Papasava and Singer, 1985). This robust phenom-

\footnotetext{
Received Dec. 2, 1994; revised Apr. 26, 1995; accepted May 22, 1995.

We appreciate the advice and facilities of Dr. Sidney B. Auerbach for tissue homogenate assays and the help of Ernesto Rodriquez with receptor autoradiography. This work was supported by USPHS Grant NS-30697.

Correspondence should be addressed to Dr. B. G. Hoebel, Department of Psychology, Program in Neuroscience, Princeton University, Green Hall, Princeton, NJ 08544-1010.
}

Copyright (C) 1995 Society for Neuroscience $0270-6474 / 95 / 156640-11 \$ 05.00 / 0$ cnon gencralizes across different classes of drugs (alcohol, opioids, sedatives, dissociative anesthetics, cannabinoids, stimulants), different species (primates or rodents) and various routes of administration (Carroll and Meisch, 1979; Oei, 1983; Carroll, 1985; Papasava et al., 1986).

The reinforcing value of food-related stimuli and drug intake has been repeatedly associated in previous studies with the activity of the mesoaccumbens dopamine (DA) system (Hoebel et al., 1983, 1992, in press; Hernandez et al., 1987; Schultz et al., 1993; Gratton, 1994; Mark et al., 1994). Therefore, chronic food deprivation may alter basal DA release in the nucleus accumbens (NAC), which in turn may change the response of the system to different classes of drugs (i.e., psychostimulants and opiates) and to natural reinforcers such as food-related stimuli. In the present study, in vivo microdialysis was used to monitor extracellular DA in the NAC, the dorsal striatum (STR) and the medial prefrontal cortex (PFC) of underweight and control, freely moving rats. In other groups, homogenate assays were performed to measure the combined intracellular and extracellular DA pools. Since $D_{1}$ and $D_{2}$ receptors have been closely involved in the regulation of feeding behavior (Schneider et al., 1988; Angel, 1990; Clifton et al., 1991; Cooper et al., 1992; 'Terry and Katz, 1992; Tyrka et al., 1992), we also used receptor binding in NAC and STR micropunches as well as quantitative receptor autoradiography to examine differences in $D_{1}$ and $D_{2}$ density as a function of weight loss.

\section{Materials and Methods}

Experimental design. A total of 105 underweight and 114 control rats were used in the series of experiments described below. Separate subjects participated in each experiment in order to avoid drug interactions. Basal locomotor activity measurements were taken from subjects that participated in the microdialysis experiments, a total of 27 underweight and 26 controls. For cach experiments, subjects were divided in two groups, underweight and control, and the protocol for weight reduction (as described below) was identical in all experiments. Two-way ANOVA with repeated measures and post hoc Tukey lests were used for the microdialysis data to study (1) between-group differences (underweight vs control), (2) within-group time differences (before and after drug injections and meal presentations), and (3) possible interaction (weight $x$ time) effects. One-way ANOVA with post hoc Tukey tests were used for the homogenate-assay and the autoradiography data to study between-group differences (underweight vs control).

Animals and surgery. Male 3 month old Sprague-Dawley rats (Princeton University, Department of Psychology Vivarium) weighing $400-500 \mathrm{gm}$ were implanted with bilateral $10 \mathrm{~mm} 21$ gauge stainless steel guide shafts leading to the posterior NAC, medial PFC or dorsal STR. The stcreotaxic coordinates for the $\mathrm{N} \Lambda \mathrm{C}$ were $10.1 \mathrm{~mm}$ anterior (A) to interaural zero, $1.2 \mathrm{~mm}$ lateral (L) to the midsagittal sinus, and 
$4 \mathrm{~mm}$ perpendicularly ventral (V) to the level skull surface; for PFC, $12.5 \mathrm{~A}, 0.75 \mathrm{~L}$, and $2.0 \mathrm{~V}$; for STR, $10.0 \mathrm{~A}, 3.0 \mathrm{~L}$, and $2.0 \mathrm{~V}$. The microdialysis probe protruded another $4 \mathrm{~mm}$ ventral to the tip of the guide shaft. Following surgery animals were individually housed with food and water available ad libitum on a $12 \mathrm{hr}$ on/12 hr off light cycle (lights on 10:30 P.M.; off 10:30 A.M.). At least 1 week was allowed for recovery. The subjects in the homogenate and receptor binding experiments described below did not undergo surgery.

Microdialysis probes and HPLC. The microdialysis probes were made of concentric 36 gauge stainless steel tubing inside of 26 gauge tubing with a $200 \mu \mathrm{m} \times 2 \mathrm{~mm}$ hollow cellulose tip that allowed diffusion of neurochemicals with a molecular weight less than 6000 . The probes had a relative recovery of about $10 \%$ depending on the neurochemical (Hernandez et al., 1986). Syringe pumps with gas-tight syringes $(2.5 \mathrm{ml})$ perfused a continuous stream of Ringer's solution (146 $\mathrm{mm} \mathrm{NaCl} ; 3.9 \mathrm{~mm} \mathrm{KCl} ; 1.2 \mathrm{mM} \mathrm{CaCl}_{2 ;} 1 \mathrm{mM} \mathrm{MgCl}$; $\mathrm{pH} 7.4$ ) at a rate of $1 \mu \mathrm{l} / \mathrm{min}$ through the dialysis probes. The perfusate was collected in sampling vials and immediately injected in a high performance liquid chromatography system coupled with electrochemical detection (HPLCEC).

A coulometric detector $(5100 \mathrm{~A}$; ESA Inc.) was used to measure DA, the dopamine metabolites dihydroxyphenylacetic acid (DOPAC) and homovanillic acid (HVA) and the serotonin metabolite 5-hydroxyindoleacetic acid (5-HIAA). Samples from microdialysates or homogenates $(25 \mu \mathrm{l}$ each) were injected into a $50 \mu \mathrm{l}$ valve loop leading to a $10 \mathrm{~cm}$ phase II column (Brownlee Labs) with $3.2 \mathrm{~mm}$ bore and $3 \mu \mathrm{m}$, C-18 packing. The mobile phase contained $60 \mathrm{~mm} \mathrm{NaH} \mathrm{PO}_{4}$ (sodium phosphate monobasic), $100 \mu \mathrm{M}$ EDTA, $1 \mathrm{mM}$ heptanesulfonic acid, and $2 \% \mathrm{v} / \mathrm{v}$ methanol. The $\mathrm{pH}$ was adjusted to 3.6 with phosphoric acid. Output was relayed to a dual-pen chart recorder (Linseis Inc.). Neurochemicals eluted in about $25 \mathrm{~min}$ in the following order: DOPAC, DA, 5-HIAA, HVA. Peaks were identified by comparison to retention times of $1 \mathrm{pg} / \mu \mathrm{l}$ and $10 \mathrm{pg} / \mu \mathrm{l}$ standards injected in the HPLC on a daily basis.

An amperometric detector with dual polentiostats (EGandG Princeton Applied Research Corp.) was used to measure serotonin (5-hydroxytryptamine, 5-HT) successively at $590 \mathrm{mV}$ and at $718 \mathrm{mV}$ in about 10 min. Samples $(20 \mu \mathrm{l})$ were injected in a $20 \mu \mathrm{l}$ valve loop leading to a Brownlee column as described above. The mobile phase contained $116.8 \mathrm{~mm} \mathrm{NaOH}, 144.7 \mathrm{~mm}$ monochloroacetic acid, $100 \mu \mathrm{M}$ EDTA, 1 $\mathrm{mm} 1$-octanesulfonic acid, and $1.8 \% \mathrm{v} / \mathrm{v}$ acetonitrile. The $\mathrm{pH}$ was adjusted to 3.1 with monochloroacetic acid. HPLC output was relayed to a Linseis chart recorder with recording pens assigned to each of the above oxidation potentials. Serotonin peaks were identified by comparison to both the retention time and the ratio given by the two potentials for $10 \mathrm{pg} / \mu \mathrm{l}$ and $1 \mathrm{pg} / \mu \mathrm{l}$ standards injected in the HPLC on a daily basis.

Chronic food deprivation and microdialysis. Following recovery from surgery, the microdialysis rats scheduled for weight loss were given access to a restricted amount of food (5-7 gm of chow) at the onset of the dark cycle for 7-10 d until they lost 20-30\% of their ad libitum weight. Probes were implanted at least $15 \mathrm{hr}$ before sampling. Left and right accumbens sites were counterbalanced between animals. Microdialysis sessions took place at least $3 \mathrm{hr}$ after onset of the dark cycle when rats are normally active. No food was given to either underweight or control animals for at least $3 \mathrm{hr}$ before dialysis sampling to avoid changes in basal extracellular DA from spontaneous meals before microdialysis sessions. Baseline samples were collected every $30 \mathrm{~min}$ for $2-3 \mathrm{hr}$ to establish basal extracellular DA levels. The effect of weight loss was assessed in $\mathbf{1 7}$ rats, with 13 others as controls maintained on ad libitum food intake. Next, one of four challenges was administered, (1) $1.5 \mathrm{mg} / \mathrm{kg}$ i.p. $d$-amphetamine sulfate (AMPH; Sigma Chemicals Co.) given to the same animals, (2) a $30 \mathrm{~min}$ infusion of AMPH ( $25 \mu \mathrm{M}$ in Ringer's) by reverse dialysis into the NAC of differcnt groups ( 6 underwcight and 6 controls), (3) $20 \mathrm{mg} / \mathrm{kg}$ i.p. morphine sulfate (MORPH, Sigma Chemicals Co.) with 9 underweight and 16 controls, or (4) a $30 \mathrm{~min}$ laboratory chow meal (11 underweight and 16 controls). To test anatomical specificity, the effects of weight loss and intraperitoneal amphetamine were assessed in the straitum (10 underweight, 16 controls) and prefrontal cortex (14 underweight, 9 controls). Horizontal locomotor activity was measured by two photocell beams that divided the cage into thirds. Activity was measured in underweight rats $(n=7)$ and controls $(n=12)$ that were then given i.p. amphetamine; other groups received intraperitoneal morphine ( 3 under- weight, 3 control) or a meal ( 3 underweight, 4 control). Photocell crossings were counted in $30 \mathrm{~min}$ time bins.

Histology. At the end of the microdialysis experiments animals were overdosed with sodium pentobarbital and perfused with $0.9 \%$ saline followed by $4 \%$ formaldehyde in saline. The brains were removed and stored in formaldehyde for several weeks, frozen, and sectioned at 40 $\mu \mathrm{m}$ to locate the dialysis probe tract in relation to the posterior NAC.

Homogenate assay. In the experiment to measure DA in tissue micropunches, underweight rats ( $n=13)$, after losing weight as described above, and normal weight controls $(n=15)$ were sacrificed in the middle of the dark cycle. For $3 \mathrm{~d}$ before, they were accustomed to the setting for a few minutes in order to minimize stress at the actual time of sacrifice. Brains were kept on ice for rapid dissection and the NAC and STR were each removed bilaterally from a $2 \mathrm{~mm}$ thick slice just anterior to the optic chiasm using a stainless steel $1.25 \mathrm{~mm}$ micropunch. These tissue samples were homogenized, dissolved in $0.1 \mathrm{~N}$ perchloric acid and $100 \mu \mathrm{M}$ EDTA, and centrifuged for $20 \mathrm{~min}$ at $15,000 \mathrm{rpm}$. The supernatants were analyzed for DA, 5-HT, and metabolites by HPLC-EC. Protein levels were determined from the remaining tissue pellets with the Bio-Rad Protein Assay. Neurochemical measurements were adjusted for the amount of protein per micropunch.

Receptor binding in micropunches. NAC and STR micropunches were derived as described above, homogenized and pre-incubated in a buffer of $50 \mathrm{~mm}$ Tris, $0.5 \mathrm{~mm}$ EDTA, and $5 \mathrm{~mm} \mathrm{MgSO}$ (18 underweight, 16 controls). These tissue samples were incubated with $1 \mathrm{nM}$ ${ }^{3} \mathrm{H}$-SCH23390 for $\mathrm{D}_{1}$-type binding or $1 \mathrm{nM}{ }^{3} \mathrm{H}$-spiperone for $\mathrm{D}_{2}$-type binding in a buffered solution containing $40 \mathrm{nM}$ ketanserin; $1 \mu \mathrm{M}$ flupenthixol was used to define nonspecific binding. The ligand bound to the membranes was separated from that remaining free in solution by filtration under reduced pressure over glass fiber filters (Crecsc, 1983). Bound ligand on the filter was counted by a liquid scintillation spectrometer (Beckman Instrument Co.).

Quantitative receptor autoradiography. Animals (seven underweight, seven controls) were sacrificed and brains were frozen in cold isopentane. Slices $(20 \mu \mathrm{m}$ thick) were cut at the level of frontal cortex, anterior NAC-STR, posterior NAC-STR and hypothalamus (lateral, ventromedial, dorsomedial, and periventricular). All slices were mounted on subbed slides for incubation. The ligands used were $1 \mathrm{nM}{ }^{3} \mathrm{H}-\mathrm{SCH} 23390$ $\left(D_{1}\right)$ and $1 \mathrm{nM}{ }^{3} \mathrm{H}$-spiperone $\left(D_{2}\right)$ in the same incubation buffer described above. After incubation for $60 \mathrm{~min}$, slices were exposed on light proof Kodak D-19 film for 2-6 weeks depending on the brain site. The developed films were analyzed with the Microcomputer Imaging Device program (Imaging Res., Inc., Ontario, Canada) in order to subtract nonspecific binding of the ligand to cellular components other than the receptors of interest (Bylund and Yamamura, 1990; Kuhar and Unnerstall, 1990)

\section{Results}

\section{Effect of food restriction on body weight}

The mean of body weights in all experiments was $501.4 \pm 8.7$ gm for normal rats versus $386 \pm 9.1 \mathrm{gm}$ for underweight rats (77\% of own ad libitum starting weight; Fig. 1).

\section{Nucleus accumbens: effect of weight loss on basal DA}

Basal extracellular DA in the NAC of four groups of underweight rats was significantly below the corresponding control group in each of the four experiments $[F(1,400)=12.458, p<$ $0.0005]$. Restricted food intake and weight loss reduced extracellular DA to half normal in the first experiment (see baselines in Fig. $2 A$ ). Mean basal extracellular DA in the NAC was 0.02 $\pm 0.002 \mathrm{pmol} / 25 \mu \mathrm{l}$ sample (mean $\pm \mathrm{SEM}$ ) for underweight rats $(n=17)$ and $0.04 \pm 0.02 \mathrm{pmol} / \mathrm{sample}$ for control rats $(n$ = 13). A two-way ANOVA with repeated measures followed by post hoc Tukey tests showed that basal DA level in the NAC was significantly lower in the underweight than the control group $[F(1,28)=7.217, p<0.01]$. Basal extracellular HVA was also significantly lower in underweight rats $[3.22 \pm 0.30$ pmoles/sample vs $7.79 \pm 1.01 \mathrm{pmol} / 25 \mu \mathrm{l}$ in controls; $F(1,27)$ $=8.143, p<0.01]$. Basal extracellular DOPAC and 5-HIAA did not differ significantly between the two groups. 


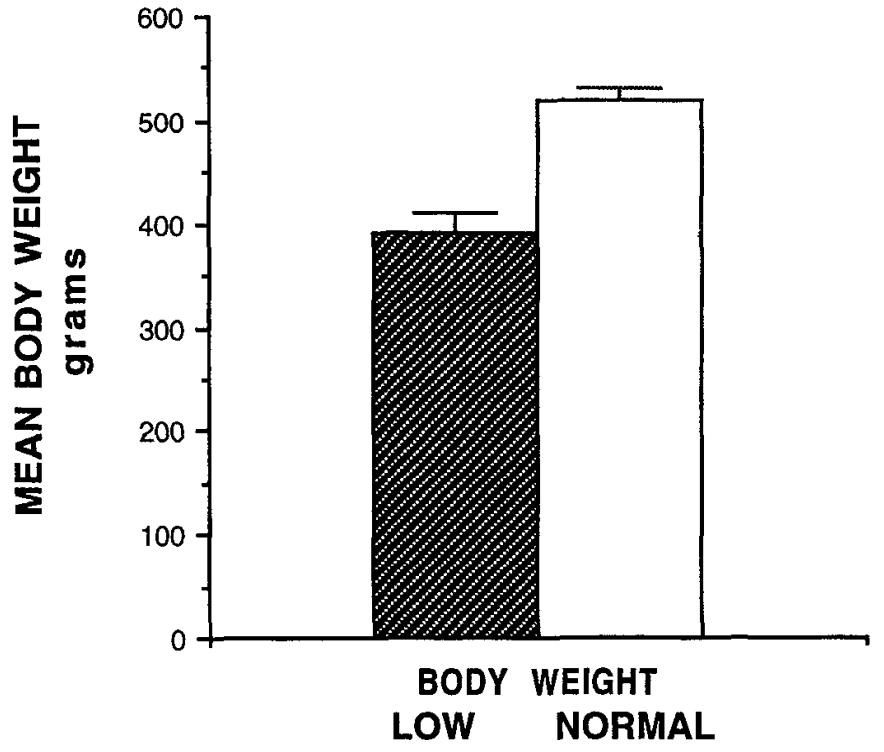

Figure 1. Grand mean body weights for the underweight and control groups. Following chronic food deprivation, the underweight group lost $23 \%$ of its ad libitum weight.

Nucleus accumbens: effects of systemic amphetamine on DA

Following measurement of basal DA, systemic d-AMPH was given in both groups. After systemic AMPH (1.5 mg/kg i.p.), extracellular DA increased in both groups, but accumbens DA remained significantly lower in the underweight animals as seen in Figure $2 A[0.05 \pm 0.01$ vs $0.10 \pm 0.02 \mathrm{pmol} /$ sample; $F(1,28)$ $=7.217, p<0.01]$. Figure $3 A$ plots the same data as percentage of mean baseline and shows that AMPH increased extracellular DA significantly in both groups $[F(13,364)=11.57, p<0.01]$ and similarly in both groups (263.8 $\pm 57.6 \%$ for underweight vs $241 \pm 56.2 \%$ for controls).

HVA after AMPH challenge remained significantly lower in the underweight than the control group $[1.71 \pm 0.30$ vs $4.35 \pm$ $1.10 \mathrm{pmol} / \mathrm{samplc} ; F(1,27)=8.143, p<0.01$ ], although AMPH decreased HVA significantly and similarly in both groups [to $52.2 \pm 8.8 \%$ and $55.8 \pm 14.2 \%$ of mean baseline in underweight and controls respectively; $F(13,351)=10.219, p<$ $0.01]$. DOPAC also decreased significantly and similarly in both groups [to $49.3 \pm 13 \%$ and $45.7 \pm 10.2 \%$ of mean baseline in underweight and controls respectively; $F(13,351)=14.139, p$ $<0.01]$. 5-HIAA levels did not change significantly in either group after AMPH.

In summary, the underweight group had low extracellular DA in the $\mathrm{NAC}$, and $1.5 \mathrm{mg} / \mathrm{kg} \mathrm{AMPH}$ transiently restored it to baseline.

\section{Nucleus accumbens: effects of local amphetamine on DA}

In separate groups of animals basal DA was $68 \%$ of normal in the underweight group, and local AMPH infusion in the NAC by reverse dialysis ( $25 \mu \mathrm{M}$ in probe Ringer's) for $30 \mathrm{~min}$ increased extracellular DA significantly over baseline in both groups $[F(7,70)=12.704, p<0.01]$, but it caused a significantly larger increase in the underweight animals $[n=6$ underweight and 6 controls; $1824.6 \pm 556.4 \%$ vs $595.9 \pm 275.6 \%$ of mean baseline respectively; $F(7,70)=4.061, p<0.01$; Fig. $3 B$ ]. Thus underweight rats released more DA than controls when the AMPH was applied directly to the terminal region in the NAC.
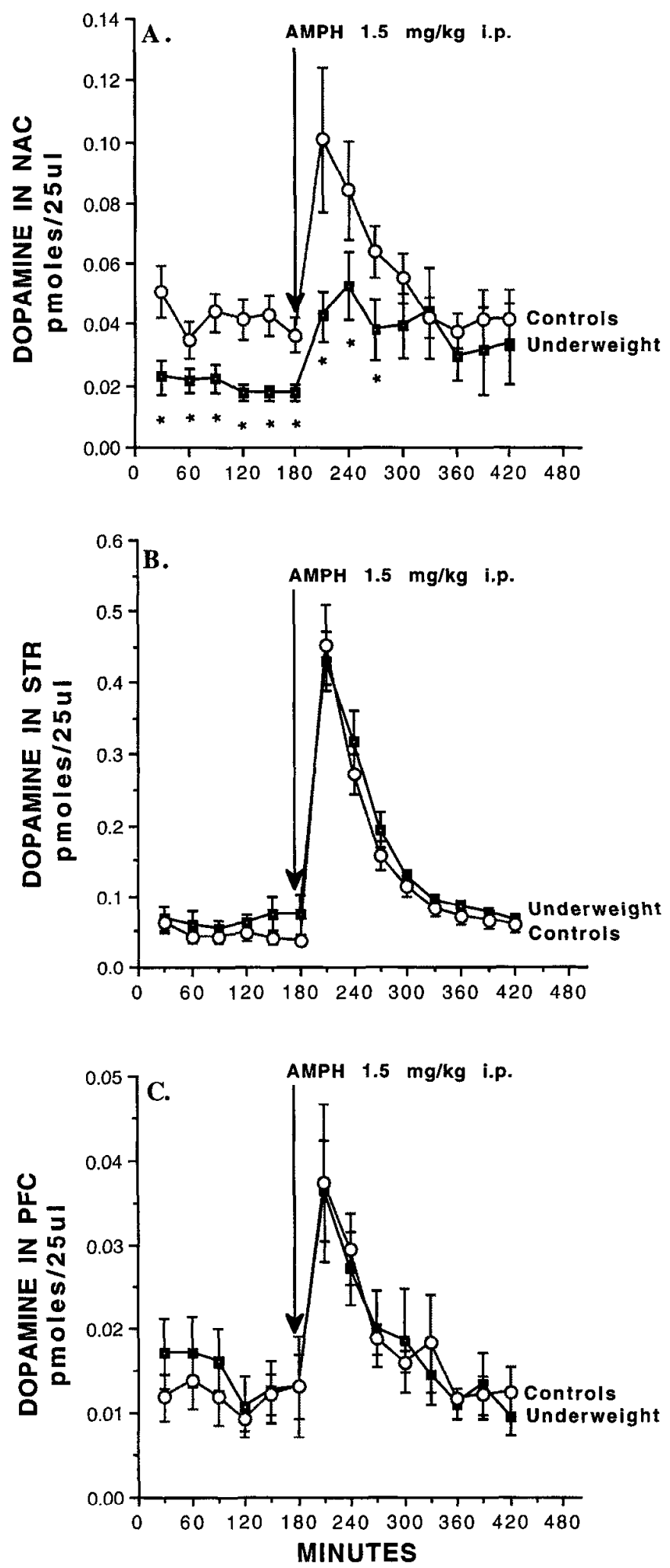

Figure 2. A, Note first that basal extracellular DA (to the left of the arrow) was low in the NAC of the underweight group $(*, p<0.01)$. Systemic amphetamine (arrow) increased DA significantly in both groups, but DA remained significantly lower in the underweight group. Basal and AMPH-challenged DA in the dorsal STR $(B)$ and medial prefrontal cortex $(C)$ did not vary as a function of body weight. 

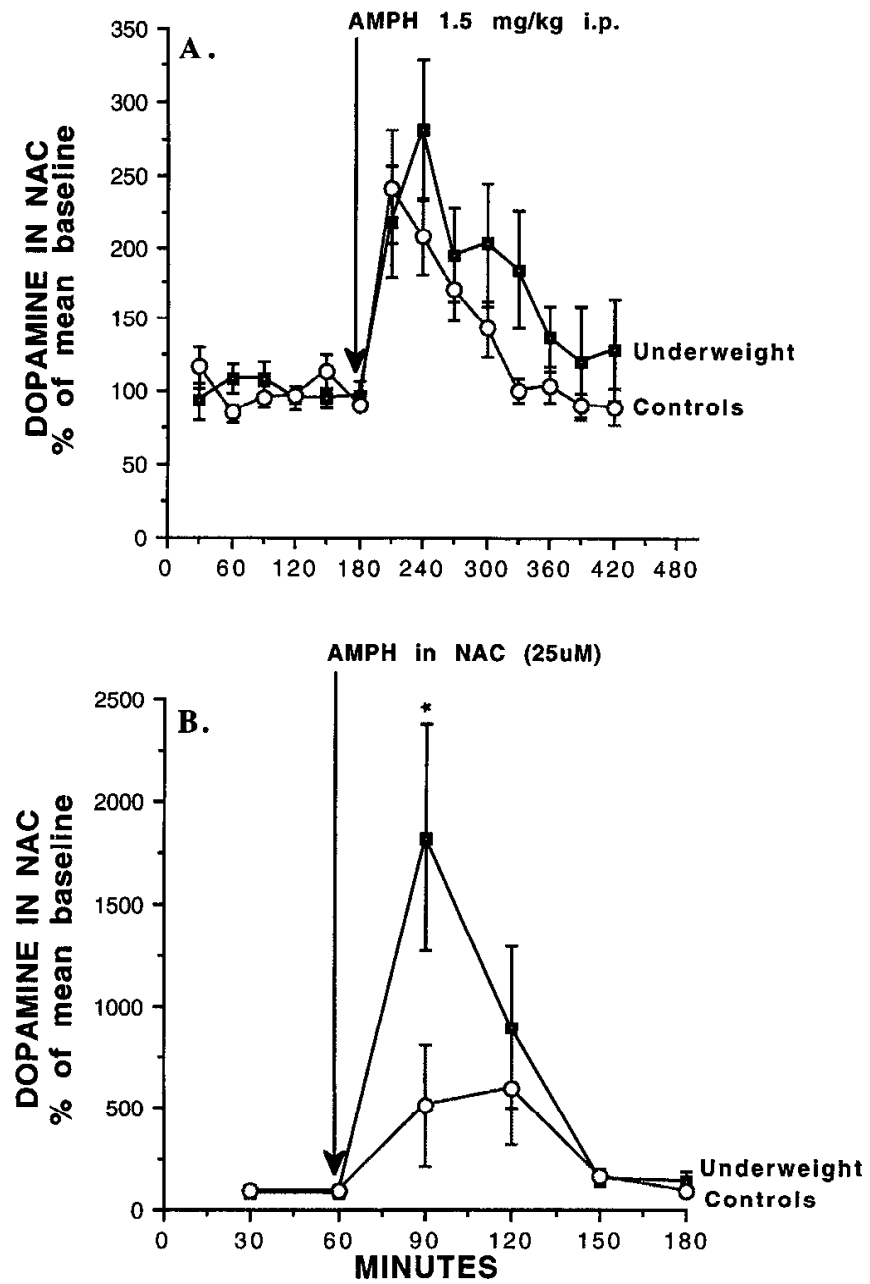

Figure 3. Although the maximum DA level in response to systemic amphetamine was lower in underweight than in control rats (shown Fig. $2 A$ ), the relative change plotted as percent change from baseline was similar in the two groups $(A)$. In contrast, AMPH infused locally into the NAC $(B)$ caused a much stronger response in the underweight than in the control group $(*, p<0.01)$.

Nucleus accumbens: effects of systemic morphine on DA

MORPH was less effective in underweight animals. Basal DA was significantly below normal (60\%), and as shown in Figure $4 A$, systemic MORPH $(20 \mathrm{mg} / \mathrm{kg}$ i.p.) increased extracellular DA significantly in both groups $[234.9 \pm 70 \%$ in underweight rats, $n=9$ vs $446.3 \pm 122.3 \%, n=16$ in controls, $F(11,253)$ $=8.971, p<0.01]$. This percent increase was significantly less in the underweight group $[F(11,253)=2.512, p<0.01]$.

MORPH produced a significant increase in all three metabolites in both groups. Specifically, DOPAC increased to $198.1 \pm$ $55.3 \%$ of mean haseline in underweight rats and $172.2 \pm 37.8 \%$ in controls $[F(11,253)=17.101, p<0.01]$; HVA to $270 \pm$ $73.4 \%$ and $251.3 \pm 59.5 \%$, respectively $[F(11,253)=25.251$, $p<0.01] ;, 5$-HIAA to $136.2 \pm 21.4 \%$ and $131.2 \pm 16.3 \%$ $[F(11,253)=5.450, p<0.01]$.

\section{Nucleus accumbens: effects of food intake on DA}

A meal was like MORPH in that it was less effective in underweight animals. Basal DA was significantly below normal ( $80 \%$ ), and Figure $4 B$ shows that after a 30 min meal of Purina chow pellets, DA in the NAC increased to $121.3 \pm 6.3 \%$ of
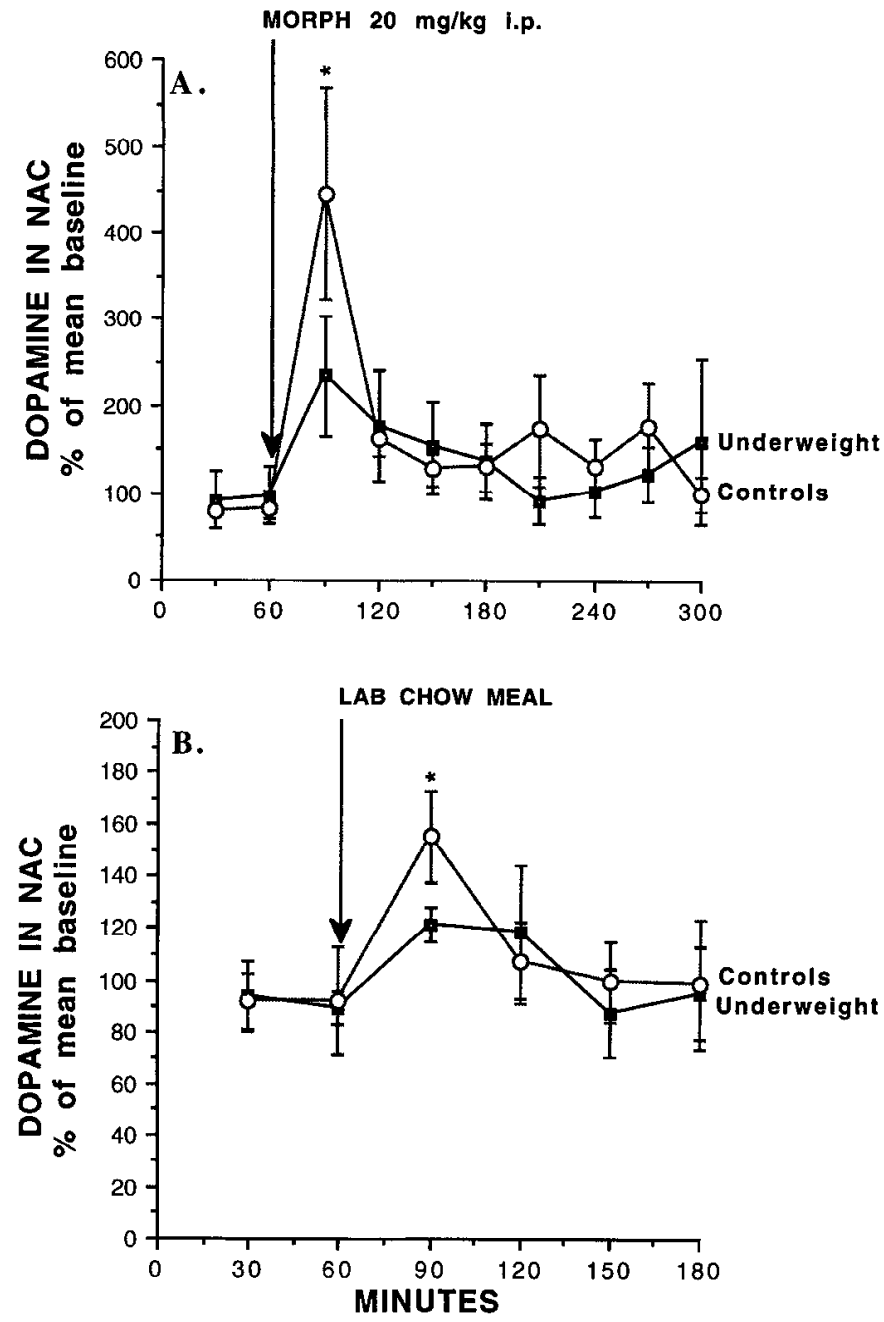

Figure 4. A, Systemic morphine induced a weak DA response in the NAC of underweight rats in comparison to controls $(*, p<0.01) . B$, Similarly, food intake in underweight rats failed to increase extracellular DA to the same degree as in controls. It is noteworthy that the diminished DA response was not due to a smaller size meal. The underweight rats did not seem to suffer from poststarvation anorexia, as they ate more than controls when given an ad libitum meal, but released less $\mathrm{DA}$ in the NAC $\left(^{*}, p<0.01\right)$

baseline in underweight rats $(n=11)$, and to $155.1 \pm 17.7 \%$ of haseline in control rats $(n=16)$. The percent increase was significant for both groups $[F(7,182)=3.832, p<0.01]$, but significantly lower for the underweight animals $[F(1,26)=$ $9.448, p<0.01]$, even though they ate more food $(7.3 \pm 0.5$ $\mathrm{gm})$ than controls $(5.6 \pm 0.3 \mathrm{gm})$. A one-way ANOVA showed that the difference in meal size was statistically significant $[F(1,25)=10.303, p<0.01]$.

As a result of the meal, HVA increased to $152.5 \pm 28 \%$ of mean baseline in underweight rats and to $120.4 \pm 23.9 \%$ of mean baseline in control rats. The increase was significant only for the underweight group $[F(7,175)=2.404, p<0.05]$. DOPAC and 5-HIAA increased, but not significantly.

Striatum: basal DA and weight loss, effects of systemic AMPH Weight loss had no detectable effects in the STR. The mean basal extracellular DA in the STR of underweight rats $(n=10)$ was $0.06 \pm 0.01 \mathrm{pmol} / \mathrm{sample}$. After AMPH (1.5 mg/kg i.p.), it increased to $0.43 \pm 0.04 \mathrm{pmoles} / \mathrm{sample}$. The mean basal extra- 

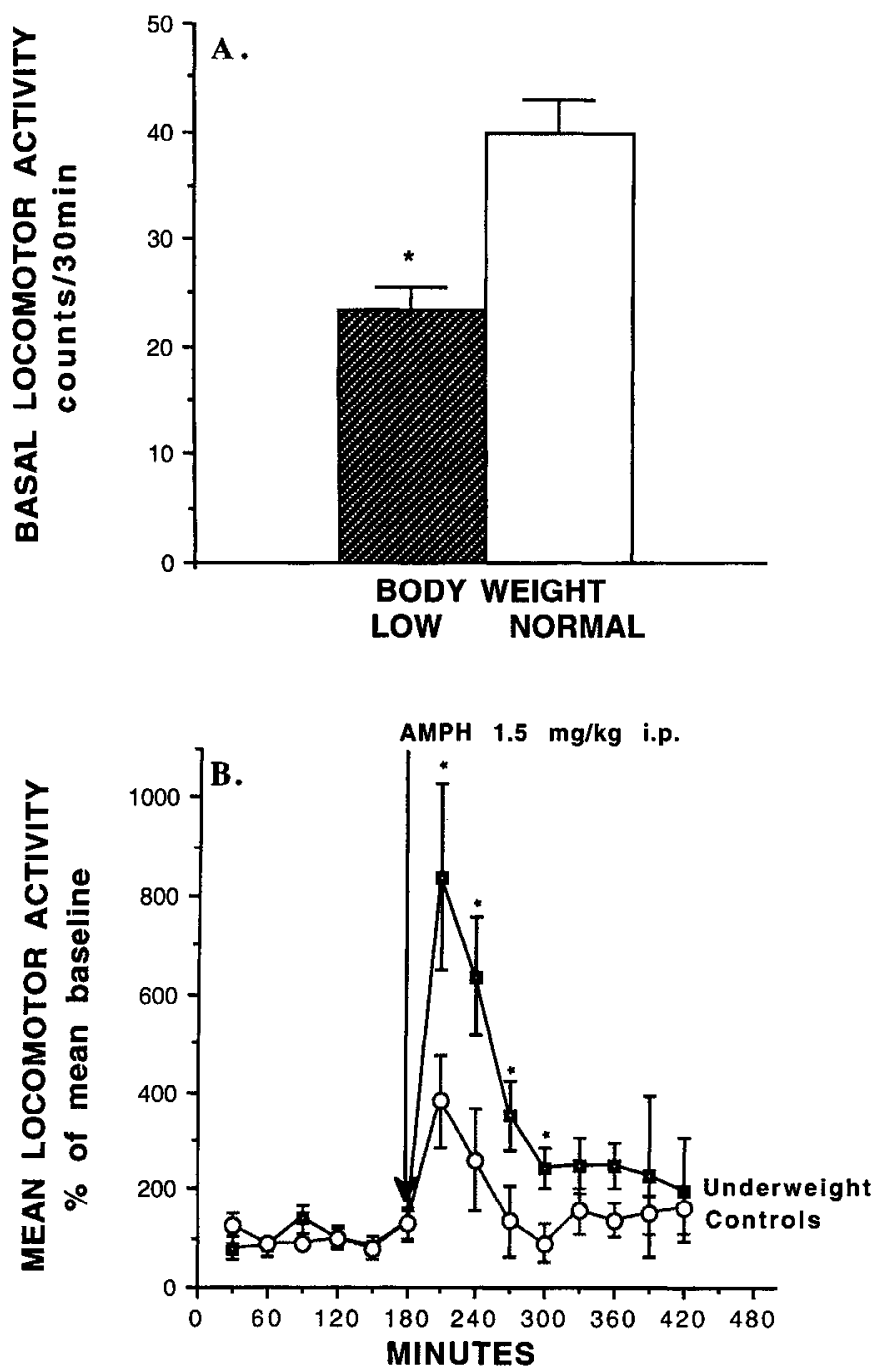

Figure 5. A, Locomotor activity during baseline microdialysis measurements was significantly less in underweight than in control rats (*, $p<0.01) . B$, The hypoactivity of underweight rats shown in $A$ was reversed after systemic AMPH. Underweight rats seem to be behaviorally supersensitive to AMPH $\left(^{*}, p<0.01\right)$

cellular DA in the STR of control rats $(n-16)$ was $0.04 \pm$ $0.01 \mathrm{pmoles} / \mathrm{sample}$. After systemic AMPH it increased to 0.45 $\pm 0.05 \mathrm{pmoles} / \mathrm{sample}$. Basal and AMPH-challenged STR DA levels did not differ significantly between the two groups (Fig. $2 B)$, and DA increased similarly over mean baseline $[F(13,247)$ $=86.599, p<0.01]$.

In the STR, basal extracellular HVA, DOPAC, and 5-HIAA in the underweight group did not differ from control levels. After AMPH, extracellular HVA and DOPAC decreased significantly in both groups [DOPAC: $25.7 \pm 3.7 \%$ vs $26 \pm 2.9 \%$, $F(13,247)=108.577, p<0.01$; HVA: $37.9 \pm 4.6 \%$ vs $44.2 \pm$ $4 \%, F(13,247)=62.600, p<0.01]$. 5-HIAA increased over baseline in both groups $[121.8 \pm 10.6 \%$ vs $125.1 \pm 9.9 \%$, $F(13,247)=11.238, p<0.01]$.

\section{Prefrontal cortex: effects of weight loss and systemic AMPH} on $D A$

In the PFC, mean basal extracellular DA was the same in underweight and control rats ( $n=14$ and $n=9$, respectively) After systemic AMPH (1.5 mg/kg i.p.), DA increased equally in

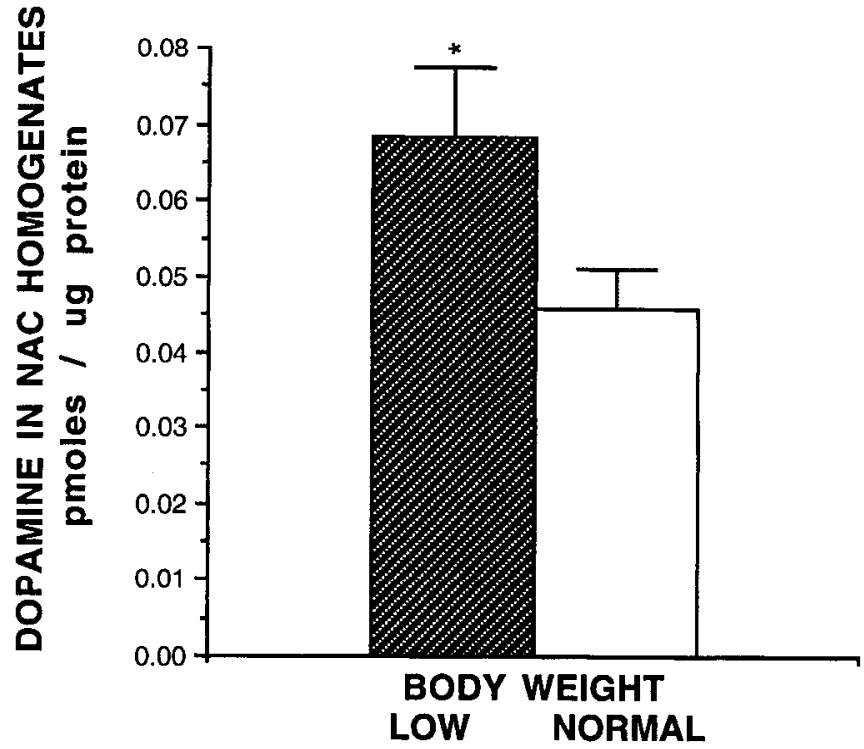

Figure 6. The sum of extracellular and intracellular DA in NAC homogenates was higher in underweight than in control rats. Therefore, the reduced DA response shown in Figure 4 is probably due to a reduction in DA release, not in DA synthesis $\left(^{*}, p<0.05\right)$.

both groups (from 0.01 to $0.04 \mathrm{pmol} / \mathrm{sample},[F(13,273)=$ $9.759, p<0.01]$ as shown in Figure $2 C$.

Extracellular HVA, DOPAC and 5-HIAA were similar in the PFC of underweight and control rats. After systemic AMPH, extracellular DOPAC and HVA decreased significantly and similarly in the PFC of underweight and control groups [DOPAC: $61.75 \pm 10.07 \%$ vs $63.66 \pm 18.1 \%, F(13,273)=4.531, p<$ 0.01 ; HVA: $70.7 \pm 6.57 \%$ vs $74.88 \pm 16.18 \%, F(13,273)=$ $5.886, p<0.01 \mathrm{~J}$. No significant changes were observed in AMPH-challenged 5-HIAA levels.

Locomotor activity: effect of weight loss, AMPH, MORPH, and a meal

Underweight animals were less active. Basal locomotor activity of underweight rats was $23 \pm 2$ (mean \pm SEM) photocell counts $/ 30$ min vs $40 \pm 3$ for the controls $[n=27$ and $n=26$; one-way ANOVA: $F(1,47)=7.436, p<0.01$; Fig. $5 A$ ]

\section{Table 1. $\mathrm{D}_{1}$-specific [ $\left.{ }^{3} \mathrm{H}\right] \mathrm{SCH} 23390$ binding (fmol/mg)}

\begin{tabular}{lcc} 
& Underweight & Controls \\
\hline Anterior NAC & $341.44 \pm 6.17$ & $341.46 \pm 9.19$ \\
Anterior DMSTR & $319.54 \pm 7.94$ & $314.68 \pm 8.17$ \\
Anterior MSTR & $325.09 \pm 9.24$ & $319.93 \pm 8.35$ \\
Posterior DLSTR & $321.73 \pm 8.67$ & $312.65 \pm 8.19$ \\
Posterior NAC & $79.86 \pm 9.45$ & $78.96 \pm 10.67$ \\
Posterior DMSTR & $113.37 \pm 5.04$ & $115.88 \pm 8.04$ \\
Postcrior MSTR & $102.97 \pm 6.19$ & $99.18 \pm 7.95$ \\
Posterior DLSTR & $108.07 \pm 6.55$ & $106.51 \pm 8.53$ \\
Ventral STR & $113.29 \pm 6.95$ & $115.19 \pm 9.87$ \\
Frontal cortex & $27.78 \pm 1.81$ & $26.19 \pm 3.74$ \\
DMH & $9.47 \pm 0.34$ & $9.92 \pm 0.8$ \\
VMH & $9.05 \pm 0.34$ & $10.12 \pm 0.89$ \\
PVN & $10.08 \pm 0.7$ & $10.46 \pm 0.99$ \\
LH & $14.8 \pm 0.77$ & $17.01 \pm 1.08$ \\
\hline
\end{tabular}


Table 2. $\mathrm{D}_{2}$-specific $\left[{ }^{3} \mathrm{H}\right]$ spiperone binding (fmol/mg)

\begin{tabular}{lcc} 
& Underweight & \multicolumn{1}{c}{ Controls } \\
\hline Anterior NAC & $135.19 \pm 4.53$ & $135.33 \pm 6.23$ \\
Anterior DMSTR & $138.42 \pm 4.74$ & $138.08 \pm 5.68$ \\
Anterior MSTR & $159.63 \pm 6.16$ & $151.28 \pm 7.86$ \\
Posterior DLSTR & $164.97 \pm 4.43$ & $164.06 \pm 6.81$ \\
Posterior NAC & $5.81 \pm 0.81$ & $4.99 \pm 1.29$ \\
Posterior STR & $11.78 \pm 1.49$ & $9.72 \pm 1.28$ \\
Frontal cortex & $8.22 \pm 1.5$ & $7.78 \pm 1.15$ \\
DMH & $8.95 \pm 2.43$ & $8.81 \pm 1.5$ \\
VMH & $30.27 \pm 2.92$ & $29.32 \pm 2.85$ \\
PVN & $5.52 \pm 1.68$ & $6.15 \pm 1.3$ \\
LH & $29.2 \pm 1.56$ & $27.94 \pm 1.95$ \\
\hline
\end{tabular}

For underweight rats given systemic AMPH ( $1.5 \mathrm{mg} / \mathrm{kg}$ i.p.), locomotor activity increased to $837 \pm 188 \%$ vs $380 \pm 95 \%$ in controls $[n=7 ; F(13,156)=4.760, p<0.01$; Fig. $5 B]$. When given local AMPH infused into the NAC, locomotor activity again increased significantly to $180 \pm 63 \%$ in the underweight group $[F(7,147)=2.748, p<0.01 ; n=11]$, but not in the control group ( $n=12)$.

Morphine ( $20 \mathrm{mg} / \mathrm{kg}$ i.p.) decreased locomotor activity to 0.7 $\pm 0.8 \%$ of mean baseline in underweight rats $(n=3)$ and to $17.6 \pm 14 \%$ in controls $(n=3)$ during the first $30 \mathrm{~min}$. Then, photocell crossings increased to $408.3 \pm 255.8 \%$ and $317.9 \pm$ $80.7 \%$, respectively, $3 \mathrm{hr}$ after the injection. Cessation of locomotion and the later hyperactivity were not different between groups.

When given access to a meal, locomotor activity increased to $561.2 \pm 442.2 \%$ in underweight rats $(n-3)$ and $352.4 \pm$ $146.2 \%$ in controls $(n=4)$. This tendency to walk around the cage during eating was not significantly different between groups.

\section{Homogenate assays for DA and 5-HT}

Total presynaptic and postsynaptic DA and 5-HT both increased in association with food restriction and weight loss. Mean DA in NAC homogenates was $0.068 \pm 0.009 \mathrm{pmol} / \mu \mathrm{g}$ protein in underweight rats and $0.046 \pm 0.005$ in control rats $\mid n=13$ and 15; one-way ANOVA: $F(1,24)=5.31, p<0.05$ : Fig. 6]. Similarly, 5-HT levels in NAC homogenates were significantly higher in the underweight group than in the control group [0.003 \pm 0.0004 vs $0.0005 \pm 0.00004 \mathrm{pmol} / \mu \mathrm{g}$ protein; $F(1,20)=$ 39.544, $p<0.01$ ]. Although total DA and 5-HT were high, DOPAC, HVA, and 5-HIAA were normal.

In the STR, homogenate DA, 5-HT, DOPAC, and 5-HIAA were similar in underweight and control rats but striatal HVA levels were significantly lower $[0.006 \pm 0.001 \mathrm{pmol} / \mu \mathrm{g}$ protein compared to $0.01 \pm 0.001$ in controls; $F(1,27)=6.782, p<$ $0.05]$.

\section{Receptor binding in micropunches}

No differences in receptor binding between normal and underweight rats were detectable. The mean $\mathrm{D}_{1}$-type binding of ${ }^{3} \mathrm{H}$ SCH23390 in NAC micropunches (after adjustment for micropunch weight) was $1066.8 \pm 83.4 \mathrm{cpm}$ in underweight rats ( $n$ $-18)$ and $1013.6 \pm 67.1$ cpin in control rats $(n=16)$. The mean $\mathrm{D}_{2}$-type binding of ${ }^{3} \mathrm{H}$-spiperone was $344.1 \pm 22.3 \mathrm{cpm}$ in underweight rats and $307.3 \pm 78.9 \mathrm{cpm}$ in controls. For the STR, underweight $(n=18)$ vs control $(n=15) \mathrm{D}_{1}$-type binding was $2153.6 \pm 82.7 \mathrm{cpm}$ vs $2044.9 \pm 130.7 \mathrm{cpm}$. $\mathrm{D}_{2}$-type binding was $697.4 \pm 44.5 \mathrm{cpm}$ vs $746.5 \pm 33.2 \mathrm{cpm}$.

\section{Quantitative receptor autoradiography}

No differences were seen in mean $\mathrm{D}_{1}$ or $\mathrm{D}_{2}$-type binding in NAC, dorsomedial STR (DMSTR), medial STR (MSTR), dorsolateral STR (DLSTR), frontal cortex (CX), dorsomedial hypothalamus (DMH), ventromedial hypothalamus (VMH), paraventricular nucleus of the hypothalamus (PVN), and lateral hypothalamus $(\mathrm{LH})$ of underweight $(n \neq 7)$ and control rats $(n=$ 7; Tables 1, 2; Fig. 7A,B).

\section{Discussion}

Following chronic food deprivation and body weight reduction to $70-80 \%$ of normal, basal extracellular DA in the NAC, but not in the STR or the PFC, decreased $20-50 \%$. The reduction in basal DA levels was accompanied by a significant reduction in HVA levels, which suggests that extracellular DA turnover was low in underweight rats. This between-group study replicates and extends an earlier preliminary report (Hoebel and Hernandez, 1990) and within-group study showing the effect of weight loss on DA in the NAC (Pothos et al., 1989, in press; Hoebel et al., 1990).

The low extracellular DA levels could theoretically reflect a variety of changes such as (1) increased intracellular DA metabolism, (2) attenuation in DA synthesis, (3) amplification of the active reuptake process, or (4) simply a decrease in DA release. Extracellular DOPAC is thought to reflect changes in the intraccllular DA pool (Zetterstrom et al., 1986). Therefore, in the present study, the absence of a significant reduction in DOPAC levels suggests that intracellular DA levels were not reduced by chronic food deprivation and weight loss. To the contrary, the overall sum of extracellular and intracellular DA in NAC homogenates was higher in underweight animals than in controls, suggesting DA was synthesized but not released, so that it accumulated in the DA neurons. The DA uptake transporter could contribute by maintaining storage pools (Horn, 1990). The whole process is related to the firing rate of relevant midbrain DA cell bodies. Firing at a lower rate in underweight rats would release less DA in the NAC and explain the observed results. The absence of an effect in the STR or the PFC is interesting and may be an indication that the VTA-NAC pathway mediates some unique aspect of motivation as it relates to food restriction and weight loss.

Receptor binding in NAC micropunches and quantitative au-

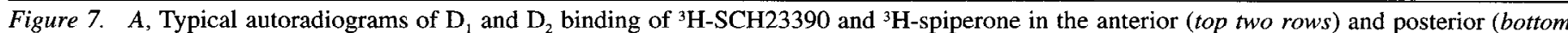

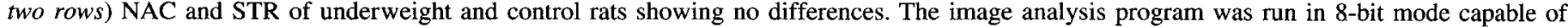

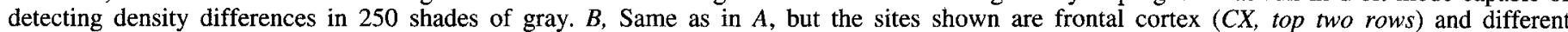

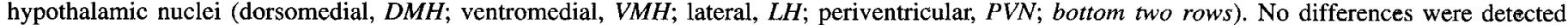
between underweight and normal rats. 
A

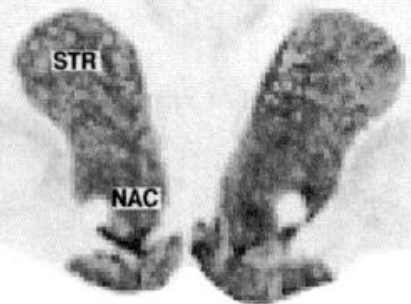

RAT 44 - UNDERWEIGHT

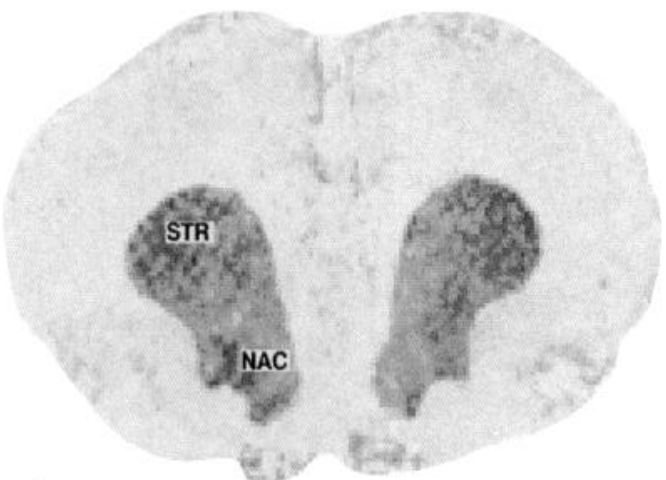

RAT 50 - UNDERWEIGHT

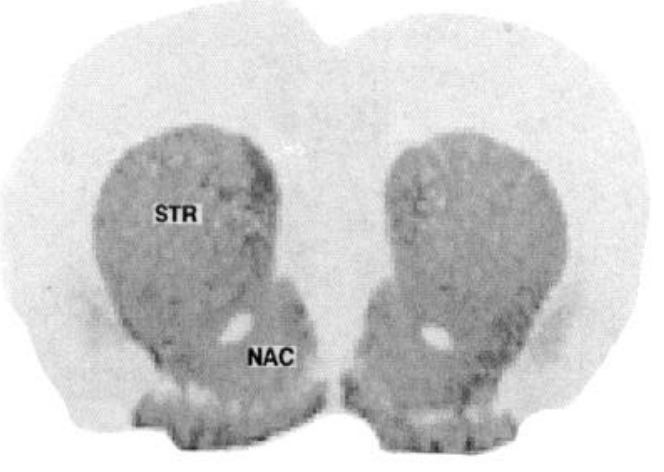

RAT 42 - UNDERWEIGHT

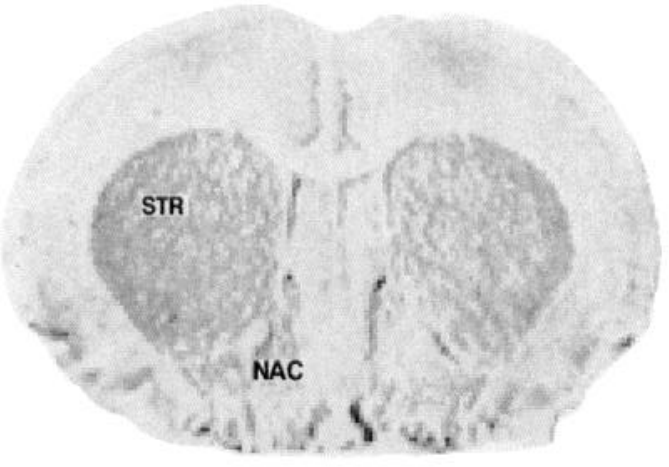

RAT 44 - UNDERWEIGHT

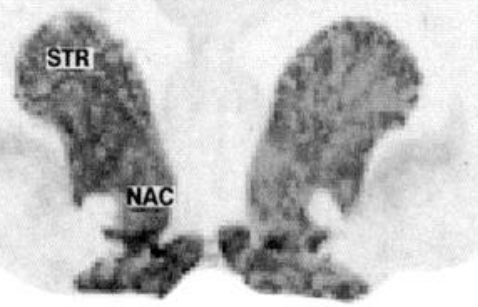

RAT 37 - CONTROL

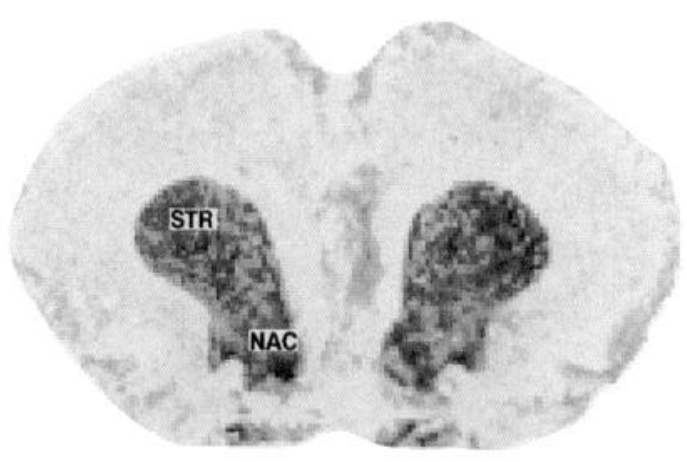

RAT 53 - CONTROL

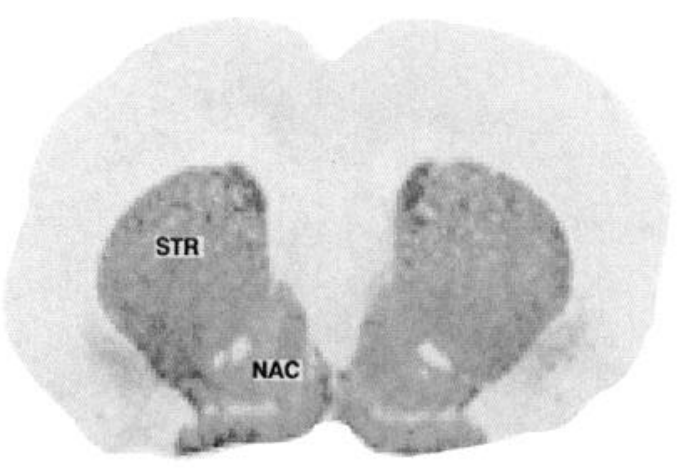

RAT 47 - CONTROL

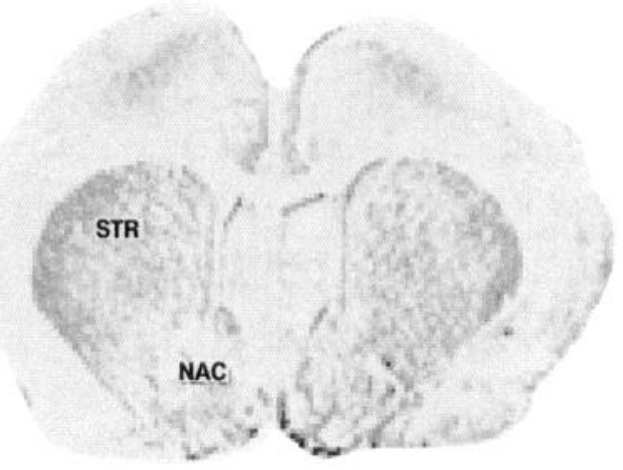

RAT 53 - CONTROL 


\section{B}

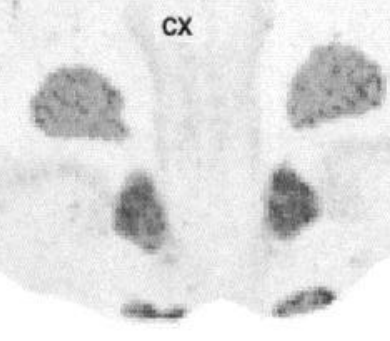

RAT 50 - UNDERWEIGHT

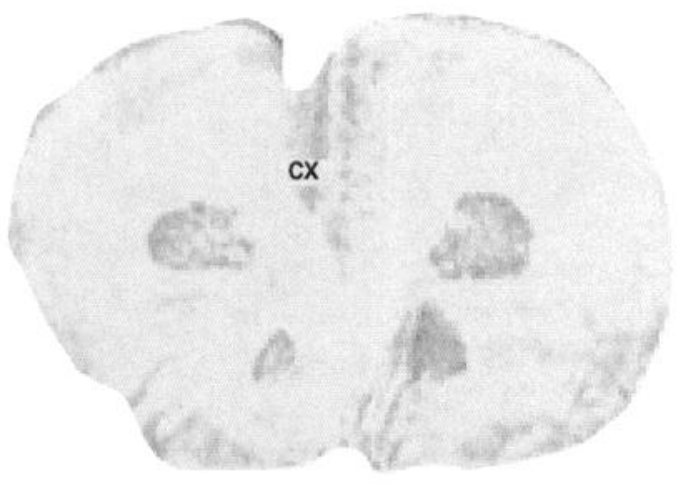

RAT 34 - UNDERWEIGHT

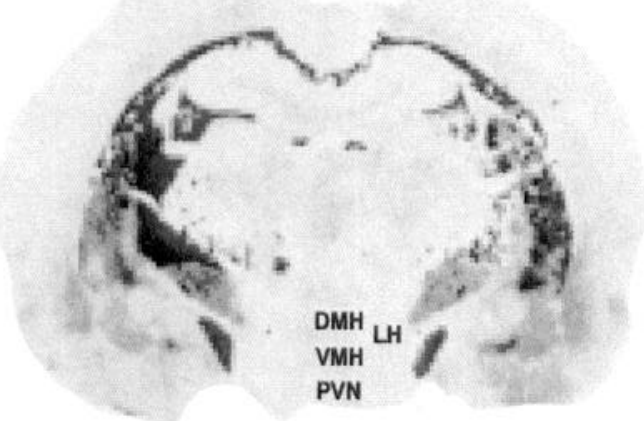

RAT 42 - UNDERWEIGHT

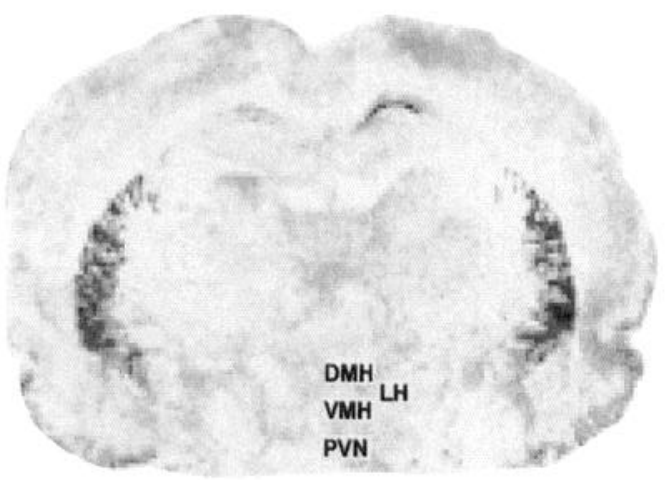

RAT 36 - UNDERWEIGHT

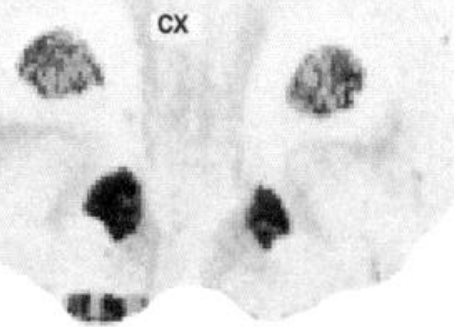

RAT 43 - CONTROL

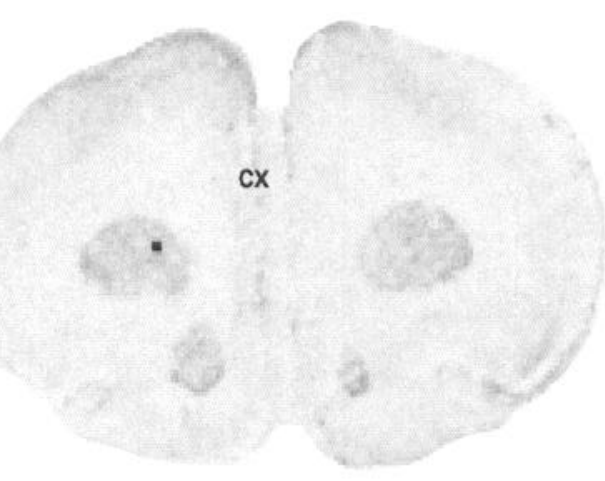

RAT 47 - CONTROL

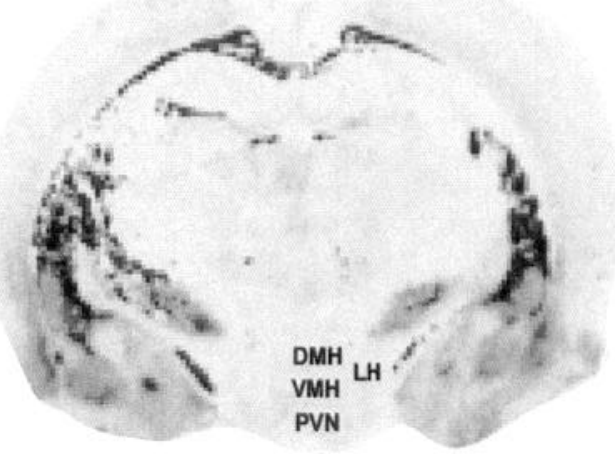

RAT 43 - CONTROL

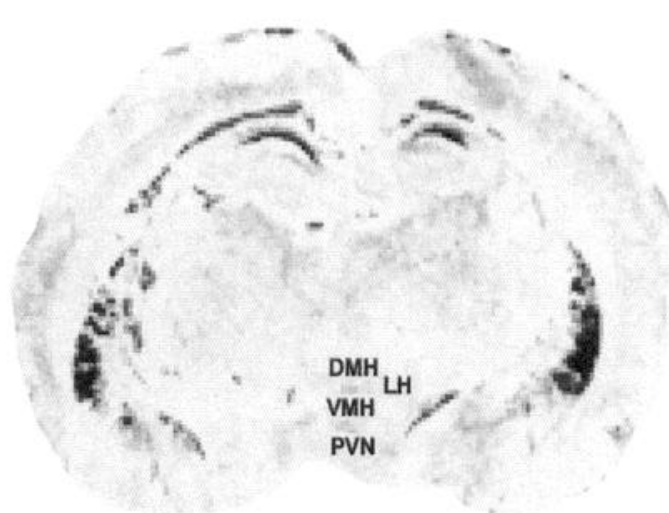

RAT 3 - CONTROL 
toradiography revealed no differences in DA receptor density between normal and underweight rats. Therefore the depression in extracellular DA levels seems to be related to attenuated presynaptic transmitter release that was not accompanied by postsynaptic supersensitivity in the receptors that were measured. Although $\mathrm{D}_{1}$ - and $\mathrm{D}_{2}$-type receptor densities are often affected by changes in DA turnover, blockade or denervation (Weinstock et al., 1978; LaHoste and Marshall, 1991), this was not detected in rats with low extracellular DA produced by the natural means of food restriction and weight loss.

In spite of the apparent lack of receptor upregulation, there could be receptor supersensitivity after starvation. SCH23390 and spiperone bind $\mathrm{D}_{1}{ }^{-}$and $\mathrm{D}_{2}$-type receptors nonselectively within each receptor family. Therefore changes in the density of receptor subtypes within the $D_{1}$ family $\left(D_{1}, D_{5}\right)$, or $D_{2}$ family $\left(D_{2}, D_{3}, D_{4}\right)$ may be difficult to detect if the relevant change occurs in a small, select portion of the receptors. In addition, $D_{1}$-type and $D_{2}$-type receptors within mesolimbic areas have high DA affinity that can change without a change in receptor density (Snyder, 1990; Sokoloff et al., 1990; Grandy et al., 1991; Sunahara et al., 1991; Levesque et al., 1992). Decreased stimulation of $D_{2}$ receptors, however, does not necessarily increase $\mathrm{D}_{2}$ sensitivity due to an unknown compensatory mechanism (Mereu et al., 1987). In sum, changes in DA receptor number are not always reflected in behaviors mediated by DA, and behavioral signs of DA receptor supersensitivity are not necessarily accompanied by changes in receptor density (Eisenberg et al., 1982; Segal and Kuczenski, 1992; Reddy et al., 1993). On the other hand, the apparent lack of $D_{1}-$ and $D_{2}$-type compensation for decreased extracellular DA in the NAC in the present study is perfectly compatible with the fact that underweight animals engage in more behaviors that release DA from presynaptic stores (i.e., more feeding or drug intake). If receptors compensated for decreased DA release, one would not expect an increase in DA-releasing behaviors.

Given the involvement of mesoaccumbens DA in the mediation of food and drug reinforcement, the selective reduction of basal DA in the NAC of underweight rats may code a motivational state associated with starvation and conducive to eating and drug intake. Some models of feeding disorders suggest that starvation and refeeding may lead to "addiction" to certain eating practices that involve a state of "food withdrawal" (Bachmann and Rohr, 1983; Szmukler and Tanlanl, 1984; Ploug and Pirke, 1987; Hoebel et al., 1992). Viewing starvation as a withdrawal syndrome is interesting in the light of evidence that extracellular accumbens DA is also low in rats undergoing morphine, ethanol, cocaine, or AMPH withdrawal (Pothos et al., 1991; Acquas and Di Chiara, 1992; Rossetti et al., 1992; Persico et al., 1993). The DA depression in underweight rats may relate to aversive properties of food withdrawal or to chronic stress associated with starvation. Although acute stressors, such as tail pinch, foot shock or restraint have been found to increase DA in the NAC (Abercrombie et al., 1989; Salamone, 1991; Imperato et al., 1992), repeated exposure to stress can attenuate the DA response and even decrease the activity of DA neurons (Imperato et al., 1992; Sato and Kumamoto, 1992). Low DA may contribute to locomotor inactivity and aversive states associated with those stressors.

In the present experiments, underweight animals were hypoactive in comparison to controls. Other studies report that fasting also dampens the sympathetic nervous system in rodents (Griggio et al., 1992). According to Mabry and Campbell (1975) food-deprived rats become hyperactive only when a novel stimulus (i.e., light, food or drug injection) is introduced in their environment. Indeed, we observed a significant increase in the locomotor activity of the underweight group versus the control group after systemic AMPH or local AMPH infusion in the NAC. Low sympathetic activity and selective low DA release in the NAC may be signs that the animal is in a "no-go" state characterized by hypoactivity and lack of goal-oriented behaviors. The seeking of food reward and avoidance of starvation aversion cannot be controlled by the animals in this paradigm because the experimenter regulates food access. Therefore, it is to the animals' advantage to conserve energy. The selective depression in accumbens DA may mediate such a motivational "no-go" state. However, we hypothesize that a higher level of DA release in the NAC is preferred because it is known that they voluntarily self-inject AMPH or DA into their NAC (Hoebel et al., 1983, Dworkin et al., 1985). Consequently, when underweight rats are presented with the prospect of a meal or familiar drug self-injection, they may switch to a motivational "go" state initiated by classically conditioned stimuli that release DA (Mark et al., 1994). Then, they would actively seek out reinforcing stimuli (Rohinson and Berridge, 1993), which might further increase accumbens DA release.

The mesoaccumbens DA system was challenged in our experiments with systemic and local AMPH, systemic morphine, and food intake. In a preliminary study AMPH appeared to lose its DA-releasing effectiveness in underweight rats (Hernandez and Hoebel 1990); however, in the present study AMPH effectively increased extracellular DA, but only up to the baseline. Given that AMPH can lead to the inhibition of dopamine cells in the midbrain it was interesting to test the drug locally in the NAC. In contrast to systemic injections, local infusions of AMPH directly into the NAC caused greater DA release in underweight rats than in controls. This corresponds to what is known about AMPH's mechanism of action. It has been shown in vitro, and we have shown in vivo by microdialysis, that the drug primarily releases vesicular DA into the cytosol through vesicle deacidification (Sulzer and Rayport, 1990; Sulzer et al., 1992; Seiden et al., 1993). The elevated cytosolic DA pool is then released into the extracellular space through the DA transporter acting in reverse (Sulzer et al., 1993). Therefore, local AMPH-induced DA release will be higher than normal if the presynaptic stores are higher than normal, as was the case in the NAC of underweight rats in this study.

Morphine and food intake caused a smaller percentage increase in extracellular DA in underweight compared to normal rats. The underweight rats ate a bigger size meal than the controls, even though the DA response was weaker. We hypothesize that underweight animals may increase drug or food intake in order to receive DA-mediated reinforcement, and for that purpose they elevate drug-oriented and food-oriented responding and intake in self-administration paradigms. The literature suggests that animals titrate their drug intake (Yokel and Pickens, 1973). Rats self-injecting d-amphetamine directly into the accumbens decreased their response rate to half when half the baseline drug intake was provided automatically (Hoebel et al., 1983). The present results imply that starved, underweight animals, including people, may eat food and take drugs of abuse partly because their mesoaccumbens DA system is depressed and extracellular DA is low in the NAC. The consequence of their actions is to increase extracellular DA, but not as high as under normal conditions, which further amplifies their DA-re- 
leasing behavior. If the drug happens to be an appetite suppressant, like AMPH or cocaine, then body weight would not readily be restored, and this link between low weight and the need for DA would exacerbate the psychostimulant sclf-administration.

However, it should be noted that chronic starvation is a complex syndrome, and therefore merits consideration beyond its selective effects on accumbens DA. For example, 5-HT in NAC micropunches was higher in underweight than in control rats, although in another study extracellular 5-HT was nearly normal (Pothos et al., in press). The brain appears to defend extracellular 5-HT during food restriction. Interactions between dopanninergic, serotonergic, and other neurochemical and endocrine systems should be carefully considered before the connection between undernutrition, weight loss, and drug self-administration is to be fully understood.

\section{References}

Abercrombie ED, Keefe KA, DiFrischia DS, Zigmond MJ (1989) Differential effect of stress on in vivo dopamine release in striatum, nucleus accumbens, and medial frontal cortex. J Neurochem 52: $1655-1658$

Acquas E, Di Chiara G (1992) Depression of mesolimbic dopamine transmission and sensitization to morphine during opiate abstinence. J Neurochem 58:1620-1625.

Angel I (1990) Central receptors and recognition sites mediating the effects of monoamines and anorectic drugs on feeding behavior. Clin Neuropharmacol 13:361-391.

Bachmann M, Rohr HP (1983) A speculative illness model of overeating and anorexia nervosa. Psychol Rep 53:831 838.

Bylund DB and Yamamura HI (1990) Methods for receptor binding. In: Methods in neurotransmitter analysis (Yamamura HI, Enna SJ, Kuhar MJ, eds), pp 1-35. New York: Raven.

Carroll ME (1985) The role of food deprivation in the maintenance and reinstatement of cocaine-seeking behavior in rats. Drug Alcohol Depend 16:95-109.

Carroll ME, Meisch RA (1979) Effects of food deprivation on etonitazene consumption in rats. Pharmacol Biochem Behav 10:155-159.

Carroll ME, Stotz D (1983) Oral $d$-amphetamine and ketamine selfadministration by rhesus monkeys: effects of food deprivation. J Pharmacol Exp Ther 227:28-34.

Carroll ME, France CP, Meisch RA (1979) Food deprivation increases oral and intravenous drug intake in rats. Science 205:319-321.

Clifton PG, Rusk IN, Cooper SJ (1991) Effects of dopamine D-sub-1 and dopamine D-sub-2 antagonists on the free feeding and drinking patterns of rats. Behav Neurosci 105:272-281.

Cooper SJ, Francis J, Al-Naser H, Barber D (1992) Evidence for dopamine D-1 receptor-mediated facilitatory and inhibitory effects on feeding behaviour in rats. J Psychopharmacol 6:27-33.

Creese I (1983) Receptor interactions of neuroleptics. In: Neuroleptics: neurochemical, behavioral, and clinical perspectives (Coyle JT, Enna SJ, ed), pp 183-223. New York: Raven.

de-Wit H (1989a) Effects of food deprivation on subjective responses to d-amphetamine in humans. Pharmacol Biochem Behav 34:791795

de-Wit $\mathrm{H}$ (1989b) Effects of food deprivation on responses to marijuana in humans. Behav Pharmacol 1:177-185.

Dworkin SI, Goeders NE, Smith JM (1985) The reinforcing and rate effects of intracranial dopamine administration. In: NIDA research monograph series, Problems of drug dependence 1984 (Harris LS, ed), pp 242-248. Rockville, MD: National Institute on Drug Abuse.

Eisenberg J, et al. (1982) Dopamine receptors in a rat model of minimal brain dysfunction. Neuropsychobiology 8:151-155.

Franklin JC, Schiele BC, Brozek J, Keys A (1948) Observations on human behavior in experimental semistarvation and rehabilitation. $\mathrm{J}$ Clin Psychol 4:28-45.

Grandy DK, Zhang Y, Bouvier C, Zhou Q, Johnson RA, Allen L, Buck K, Bunzow JR, Salon J, Civelli O (1991) Multiple human $D_{5}$ dopamine receptor genes: a functional receptor and two pseudogenes. Proc Natl Acad Sci USA 88:9175-9179.

Gratton A, Wise RA (1994) Drug- and behavior-associated changes in dopamine-related electrochemical signals during intravenous cocaine self-administration in rats. J Neurosci 14:4130-4146.
Griggio MA, Richard D, Leblanc J (1992) Effects of fasting and food restriction on sympathetic activity in brown adipose tissue in mice. $\mathrm{J}$ Comp Physiol B 162:602-606.

Hernandez L, Hoebel BG (1988) Food reward and cocaine increase extracellular dopamine in the nucleus accumbens as measured by microdialysis. Life Sci 42:1705-1712.

Hoebel BG, Hernandez L (1990) Microdialysis studies of psychostimulants. In: NIDA research monograph series, Problems of drug dependence 1989 (Harris LS, ed), pp 343-344. Rockville, MD: National Institute on Drug Abuse.

Hoebel BG, Monaco AP, Hernandez L, Aulisi EF, Stanley BG, Lenard L (1983) Self-injection of amphetamine directly into the brain. Psychopharmacology 81:158-163.

Hoebel BG, Hernandez L, Mark GP, Schwartz DH, Pothos E, Steckel JM, Stone EA (1990) Brain microdialysis as a molecular approach to obesity: serotonin, dopamine cyclic-AMP. In: Obesity: towards a molecular approach (Bray GA, Ricquier D, Spiegelman BM, eds), pp 45-61. New York: Wiley-Liss.

Hoebel BG, Leibowitz SF, Hernandez L (1992) Neurochemistry of anorexia and bulimia. In: The biology of feast and famine: relevance to eating disorders (Anderson $\mathbf{H}$, ed), pp 21-45. New York: Academic.

Hoebel BG, Rada PV, Mark GP, Parada M, Puig de Parada M, Pothos E, Hernandez $L$ (in press) Hypothalamic control of accumbens dopamine: a system for feeding reinforcement. In: Molecular and genetic aspects of obesity (Bray GA, Ryan D, eds), in press. Baton Rouge: Lousiana State UP.

Horn AS (1990) Dopamine uptake: a review of progress in the last decade. Prog Neurobiol 34:387-400.

Imperato A, Angelucci L, Casolini P, Zocchi A, Puglisi-Allegra S (1992) Repeated stressful experiences differently affect limbic dopamine release during and following stress. Brain Res 577:194-199.

Kuhar MJ, Unnerstall JR (1990) Receptor autoradiography. In: Methods in neurotransmitter receptor analysis (Yamamura HI, Enna SJ, Kuhar MJ, eds), pp 177-218. New York: Raven.

LaHoste GJ, Marshall JF (1991) Chronic eticlopride and dopamine denervation induce equal nonadditive increases in striatal D2 receptor density: autoradiographic evidence against the dual mechanism hypothesis. Neuroscience 41:473-481.

Levesque D, Diaz J, Pilon C, Martres M, Giros B, Souil E, Schott D, Morgat J, Schwartz J, Sokoloff P (1992) Identification, characterization, and localization of the dopamine $\mathrm{D}_{3}$ receptor in rat brain using 7- $\left[{ }^{3} \mathrm{H}\right]$ hydroxy-N,N-di-n-propyl-2-aminotetralin. Proc Natl Acad Sci USA 89:8155-8159.

Mabry PD, Campbell BA (1975) Potentiation of amphetamine induced arousal by food deprivation: effect of hypothalamic lesions. Physiol Behav 14:85-88.

Mark GP, Smith SE, Rada PV, Hoebel BG (1994) An appetitively conditioned taste elicits a preferential increase in mesolimbic dopamine release. Pharmacol Biochem Behav 48:651-660.

Mereu G, Hu X, Wang RY, Westfall TC, Gessa GL (1987) Failure of subchronic lisuride to modify A10 dopamine autoreceptors sensitivity. Brain Res 408:210-214.

Oei TPS (1983) Effects of body weight reduction and food deprivation on cocaine self-administration. Pharmacol Biochem Behav 19:453455.

Papasava M, Singer G (1985) Self-administration of low-dose cocaine by rats at reduced and recovered body weight. Psychopharmacology 85:419-425.

Papasava M, Singer G, Papasava C (1986) Food deprivation fails to potentiate intravenous self-administration of fenfluramine in naive rats. Appetite 7:55-61.

Persico AM, Schindler CW, Brannock MT, Gonzalez AM, Surratt CK, Uhl GR (1993) Dopaminergic gene expression during amphetamine withdrawal. Neuroreport 4:41-44.

Ploog DW, Pirke KM (1987) Psychobiology of anorexia nervosa. Psych Med 17:843-859.

Pothos E, Mark GP, Hernandez L, Hoebel BG (1989) In vivo dialysis measurements of dopamine and serotonin release in the nucleus accumbens as a function of body weight. Xth Int Conf Physiol Food Fluid Intake. Paris.

Pothos E, Rada P, Mark GP and Hoebel BG (1991) Dopamine microdialysis in the nucleus accumbens during acute and chronic morphine, naloxone-precipitated withdrawal and clonidine treatment. Brain Res $566: 348-350$ 
Pothos E, Hernandez L, Hoebel BG (in press) Chronic food deprivation decreases extracellular dopamine in the nucleus accumbens: implications for a possible neurochemical link between weight loss and drug abuse. Obesity Res, in press.

Reddy PL, Veeranna, Thorat SN, Bhargava HN (1993) Evidence for the behavioral supersensitivity of dopamine D2 receptors without receptor up-regulation in morphine-abstinent rats. Brain Res 607:293300.

Robinson TE, Berridge KC (1993) The neural basis of drug craving: an incentive-sensitization theory of addiction. Brain Res Rev 18:247291.

Rossetti ZL, Hmaidan Y, Gessa GL (1992) Marked inhibition of mesolimbic dopamine relcasc: a common feature of cthanol, morphinc, cocaine and amphetamine abstinence in rats. Eur J Pharmacol 221: 227-234.

Salamone JD (1991) Behavioral pharmacology of dopamine systems: a new synthesis. In: The mesolimbic dopamine system: from motivation to action (Willner P, Scheel-Kruger J, eds), pp 599-613. New York: Wiley.

Sato Y, Kumamoto Y (1992) Psychological stress and sexual behavior in male rats. II. Fffect of psycholngical stress on dopamine and its metabolites in the critical brain areas mediating sexual behavior. Nippon Hinyokika Gakkai Zasshi 83:212-219.

Schneider LH, Greenberg D, Smith GP (1988) Comparison of the effects of selective D-sub-1 and D-sub-2 receptor antagonists on sucrose sham feeding and water sham drinking. Ann NY Acad Sci 537: 534-537.

Schultz W, Apicella P, Ljungberg T (1993) Responses of monkey dopamine neurons to reward and conditioned stimuli during successive steps of learning a delayed response task. J Neurosci 13:900-913.

Segal DS, Kuczenski R (1992) Repeated cocaine administration induces behavioral sensitization and corresponding decreased extracellular dopamine responses in caudate and accumbens. Brain Res 577: $351-355$.

Seiden LS, Sabol KE, Ricaurte GA (1993) Amphetamine: Effects on catecholamine systems and behavior. Annu Rev Pharmacol Toxicol 32:639-677.

Snyder SH (1990) The dopamine connection. Nature 347:121-122.

Sokoloff P, Giros B, Martres M, Bouthene M, Schwartz J (1990) Molecular cloning and characterization of a novel dopamine receptor $\left(D_{3}\right)$ as a target for neuroleptics. Nature 347:146-151.

Sulzer D, Rayport S (1990) Amphetamine and other psychostimulants reduce $\mathrm{pH}$ gradients in midbrain dopaminergic neurons and chromaffin granules: a mechanism of action. Neuron 5:797-808.

Sulzer D, Pothos E, Sung HM, Maidment NT, Hoebel BG, Rayport S (1992) Weak base model of amphetamine action. Ann NY Acad Sci 654:525-528.

Sulzer D, Maidment NT, Rayport S (1993) Amphetamine and other weak bases act to promote reverse transport of dopamine in ventral midbrain neurons. J Neurochem 60:527-535.

Sunahara RK, Guan H, O'Dowd BF, Seeman P, Laurier LG, Ng G, George SR, Torchia J, Van Tol HHM, Niznik HB (1991) Cloning of the gene for a human dopamine $\mathrm{D}_{5}$ receptor with higher affinity for dopamine than $D_{1}$. Nature 350:614-619.

Szmukler GI, Tantam D (1984) Anorexia nervosa: starvation dependence. Br J Med Psychol 57:303-310.

Terry P, Katz JL (1992) Differential antagonism of the effects of dopamine D-sub-1-receptor agonists on feeding behavior in the rat. Psychopharmacology 109:403-409.

Tyrka A, Gayle C, Smith GP (1992) Raclopride decreases sucrose intake of rat pups in independent ingestion tests. Pharmacol Biochem Behav 43:863-869.

Weinstock M, Speiser Z, Ashkenazi R (1978) Changes in brain catecholamine turnover and receptor sensitivity induced by social deprivation in rats. Psychopharmacology 56:205-209.

Yokel RA, Pickens R (1973) Drug level of $d$ - and $l$-amphetamine during intravenous self-administration. Psychopharmacologia 34:255 264.

Zetterstrom T, Sharp T, Ungerstedt U (1986) Further evaluation of the mechanism by which amphetamine reduces striatal dopamine metabolism: a brain dialysis study. Eur J Pharmacol 132:1-9. 